\title{
A giant coronary aneurysm formed after coronary artery bypass grafting
}

\author{
Yukinori Ikegami, ${ }^{1}$ Kazuyo Kita, ${ }^{2}$ Tomoya Uchimuro, ${ }^{3}$ Motohiko Osako ${ }^{3}$
}

'Department of Cardiology, National Hospital Organization Tokyo Medical Center, Tokyo, Japan

${ }^{2}$ Department of Radiology, National Hospital Organization Tokyo Medical Center, Tokyo, Japan

${ }^{3}$ Department of Cardiovascular Surgery, National Hospital Organization, Tokyo Medical Center, Tokyo, Japan

\section{Correspondence to}

Dr Yukinori lkegami,

y.ikegami@cpnet.med.keio.ac.jp

Accepted 16 January 2015

\section{DESCRIPTION}

Although they may be initially asymptomatic, giant coronary aneurysms require monitoring, and they may also require surgical treatment to prevent negative outcomes such as myocardial infarction or death. We report a case of an 82-year-old man who was diagnosed with gastric cancer after haematemesis. A preoperative chest radiography showed cardiac silhouette dilation (figure 1). The patient underwent CT, which revealed a giant right

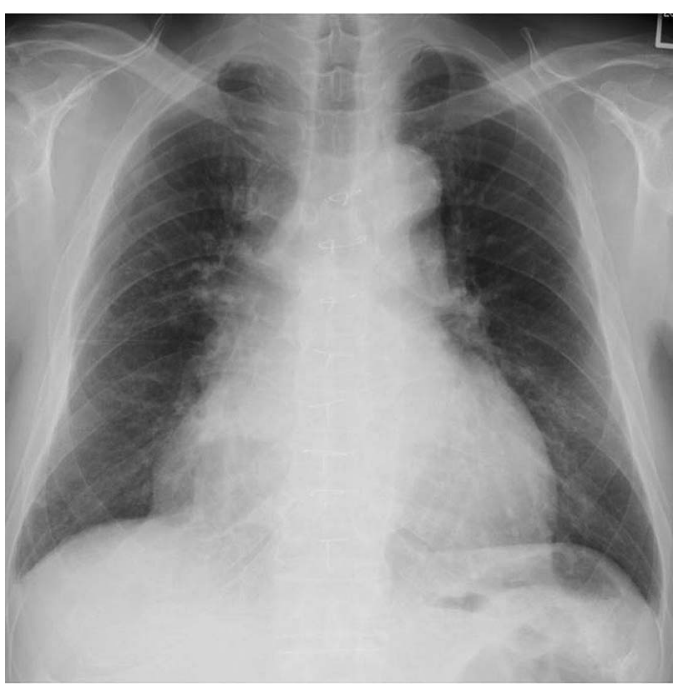

Figure 1 Posteroanterior plain chest radiograph showing a cardiac silhouette dilation. coronary aneurysm $(80 \mathrm{~mm})$ that was pressing against the right atrium and ventricle (figures 2 and 3 ). He had undergone coronary artery bypass grafting (CABG) 24 years prior and experienced heart failure (New York Heart Association (NYHA) class II) for several years. The coronary angiography performed before the CABG showed aneurysmal changes in the mid-right coronary artery, suggesting that chronic wall stress had enlarged the aneurysm. Since the coronary aneurysm was

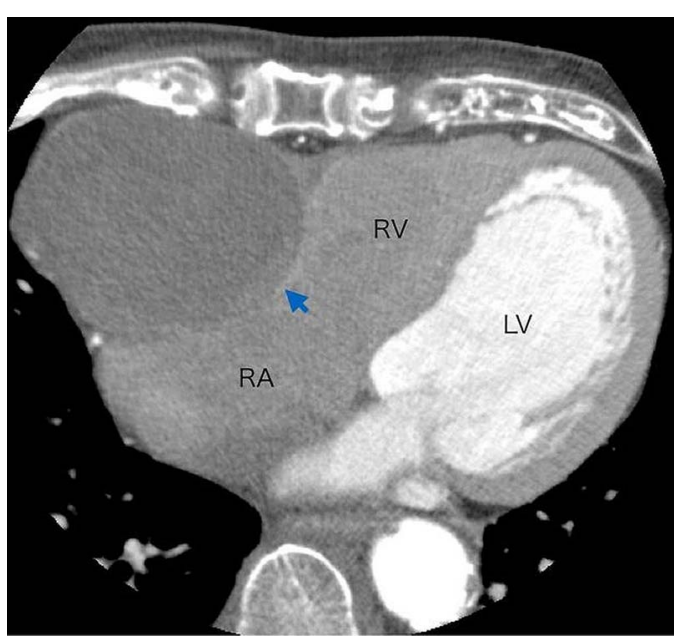

Figure 2 CT scan showing a huge mass pressing against the right atrium (RA) and ventricle (RV) (LV, left ventrical).
To cite: Ikegami $Y$, Kita $\mathrm{K}$, Uchimuro T, et al. BMJ Case Rep Published online: [please include Day Month Year] doi:10.1136/bcr-2015209308
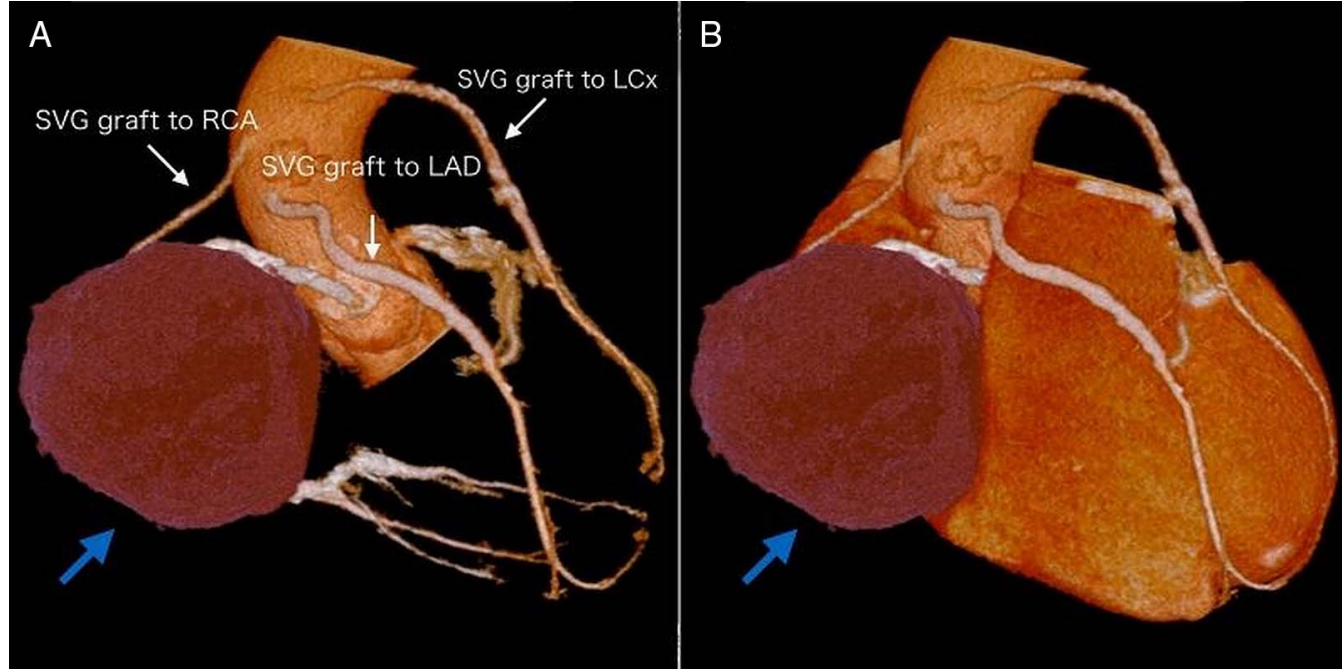

Figure 3 (A) CT three-dimensional reconstruction of the coronary arteries showing an $8 \mathrm{~cm}$ coronary aneurysm. (B) The volume rendered by the CT scan (SVG, saphenous vein graft; LAD, left anterior descending artery; RCA, right coronary artery; $L C x$, left circumflex artery). 
enlarged 6 months after surgery for gastric cancer, an additional surgery was performed to treat the aneurysm. The thrombus was depleted, and haemostasis was achieved to resolve the oozing from the aneurysm's internal surface. Since only a small

\section{Learning points}

- This case demonstrates that a coronary aneurysm can form after coronary artery bypass grafting (CABG).

- In addition, this case emphasises the importance of careful long-term clinical examination after CABG. part of the aneurysmal wall was resected because of the presence of strong adhesion, most of the aneurysmal wall was overlapped and sutured. The histological evaluation confirmed the presence of a true aneurysm. Postoperatively, the patient's heart failure improved to an NYHA class I, and his brain natriuretic peptide levels decreased from 481 to $151 \mathrm{pg} / \mathrm{mL}$ (normal $<8.5 \mathrm{pg} / \mathrm{mL}$ ). We believe that this case demonstrates a successful outcome of a rare phenomenon.

Contributors $\mathrm{YI}$ was involved with review of the literature and drafting of the manuscript. KK was involved with the drafting and radiological analysis. TU and MO were involved in the diagnostic process, operation and drafting.

Competing interests None.

Patient consent Obtained.

Provenance and peer review Not commissioned; externally peer reviewed.

Copyright 2015 BMJ Publishing Group. All rights reserved. For permission to reuse any of this content visit http://group.bmj.com/group/rights-licensing/permissions.

BMJ Case Report Fellows may re-use this article for personal use and teaching without any further permission.

Become a Fellow of BMJ Case Reports today and you can:

- Submit as many cases as you like

- Enjoy fast sympathetic peer review and rapid publication of accepted articles

- Access all the published articles

- Re-use any of the published material for personal use and teaching without further permission

For information on Institutional Fellowships contact consortiasales@bmjgroup.com

Visit casereports.bmj.com for more articles like this and to become a Fellow 